\title{
Assessing the Biomass Potential of Major Industrial Tree Plantation Species for Green Energy Production
}

\author{
Roger T. Sarmiento, Rowena P. Varela \\ College of Agricultural Sciences and Natural Resources, Caraga State University, Ampayon, Butuan City, \\ Philippines \\ Email: rpvarela@carsu.edu.ph
}

Received 27 April 2015; accepted 3 July 2015; published 6 July 2015

Copyright (C) 2015 by authors and Scientific Research Publishing Inc.

This work is licensed under the Creative Commons Attribution International License (CC BY). http://creativecommons.org/licenses/by/4.0/

(c) (;) Open Access

\begin{abstract}
Energy requirements in both urban and rural areas are increasing giving added stress to the power generators and energy sources, thus blackouts are becoming common scenarios. Renewable energy from tree biomass is being eyed to provide solution to insufficient energy supply. A component of the green energy generation project is to assess the biomass potential of major industrial tree plantation species in the region at various ages, to determine the sustainability of a biomass-based green energy generation. Actual field measurements of biomass in selected plantations were conducted. In the field inventory, a plot measuring $10 \times 50$ meters was laid out randomly on the sampling site. For all trees inside the plot, the basal diameter and diameter at breast height for ages 1 to 2 years old and 3 to 5 years old, respectively were recorded. The results revealed that the biomass of major industrial tree species in Year 1 followed the order: Mangium (Acacia mangium) > Ipil-ipil (Leucaena leucocephala) > Falcata (Paraserianthes falcataria) > Bagras (Eucalyptus deglupta). However, as the trees mature, the biomass generation changed with Falcata overtaking Mangium. The order then was: Falcata (Paraserianthes falcataria) $>$ Mangium (Acacia mangium) > Ipil-ipil (Leucaena leucocephala) > Bagras (Eucalyptus deglupta). Of the major industrial tree species, Falcata (Paraserianthes falcataria) and Mangium (Acacia mangium) are noted to have the biggest potential in supplying the biomass requirement of the green energy plant.
\end{abstract}

\section{Keywords}

Industrial Tree Plantation Species, Biomass, Green Energy Generation, Renewable Energy 


\section{Introduction}

Caraga Region, located in the northeastern part of the Mindanao Island, is tagged as the "Timber Corridor of the Philippines” due to its vast forest resources. The region has vast industrial tree plantations, making it the home to wood-based industry that produces veneer and plywood, poles, furniture and lumber. The wood-based industry of the region which largely relies on industrial tree plantations supplies approximately 70\% of the country's wood requirements (FMB, 2013). Timber production nowadays is through tree farming where small-hold farms are utilized for the production of Mangium (Acacia mangium), Falcata (Paraserianthes falcataria), Ipil-ipil (Leucaena leucocephala), and Bagras (Eucalyptus deglupta).

The advent of climate change coupled with the rising demand for food, shelter and clothing of the rapidly growing population resulted to more pressures on natural resources. Energy requirements of both urban and rural areas likewise go up causing stress to the power generators and the energy sources, thus blackouts are becoming common scenarios in the Philippines. Feasibility studies on the utilization of water resources and solar power for energy generation have been made to ease the mounting energy crisis. In Caraga Region, where tree plantations abound, renewable energy from tree biomass is also eyed to provide solution to the insufficient energy supply. Biomass largely provided energy for the Philippines particularly in rural areas where forests are located. Samson et al. (2001) cited that at the start of the $21^{\text {st }}$ century, nearly $30 \%$ of the energy used by 80 million people in the Philippines comes from biomass. Due to the available forest-based residues (e.g. twigs, tree trimmings) in rural areas, biomass seems to be common across all income brackets. Elauria et al. (2005) assessed the sustainable energy potential from non-plantation biomass resources in the Philippines. They suggested that current and future efforts of the energy sector have to focus on the development of biomass resources and efficient use in order to realize the potentials.

With the rising prices of fossil fuel-based energy, demand for both agricultural and forest biomass will increase. A component of the green energy generation project is to assess the biomass potential of major industrial tree plantation species in the region at various ages. In the region, trees generally grow faster than those in other locations in the country due to the favourable climate and fertile soils. However, limited studies in Caraga Region have been done on the biomass of trees accumulated annually considering the ecological conditions. The information can contribute in determining the viability and sustainability of a biomass-based green energy generation.

\section{Methodology}

The study was conducted in June to July 2012 in various locations of Caraga Region. The sampling sites were visited to ask permission from the owner to conduct timber inventory. These sites include: Bit-os, Manila de Bugabos, Bonbon, and the Tree Farm of Caraga State University for Butuan City; Talisay in Nasipit, DENR Compound in Maygatasan, Bayugan City; and the Tree Farm of the University of South Eastern Philippines in Maharlika, Bislig City. The study utilized both secondary data and actual field measurements. Secondary data include identification and selection of suitable sites for the sampling inventory, the location of the plantations with the required species and age class, and local and national volume tables of species.

Actual field measurements on the selected plantations with the required ages and species composition were conducted. In the field inventory, a plot measuring $10 \times 50$ meters was laid out randomly on the sampling site. For all trees inside the plot, the basal diameter $(\mathrm{BD}=0.2 \mathrm{~m}$ above ground) and diameter at breast height $(\mathrm{DBH}=$ $1.3 \mathrm{~m}$ above ground) for ages 1 to 2 years old and 3 to 5 years old, respectively were recorded. The heights of trees less than 4 meters were directly measured using a calibrated stadia rod. A telescope was used to accurately measure heights to the nearest 0.01 of a meter. For taller trees, total tree heights were determined using a Suunto clinometer involving the principles of trigonometry.

Analysis on data collected was done on the last week of the study. The tree biomass for Falcata species was computed using the allometric equations developed by the ERDS (Tandug, 1986) while tree biomass of other species was computed using the equations for the Wet Classification developed by Brown (1997).

For Falcata species by ERDS (2012) adopting Tandug (1986):

$$
Y f=10 \wedge[-0.9836+1.8036 \times \log (D)+0.8702 \times \log 10(H)]
$$

where:

$Y f=$ Fresh biomass yield of falcata in $\mathrm{kg}$.

$D=$ Diameter (BD for $<2$ years old and $\mathrm{DBH}$ for $>3$ years old) in $\mathrm{cm}$. 
$H=$ Tree height in meters

For other tree species, the following equation developed by Brown (1997) was used.

$$
Y t=\exp [-2.134+2.530 \times \ln (D B H)]
$$

where:

$$
Y t=\text { Biomass yield of tree species in } \mathrm{kg} \text {. }
$$

\section{Results and Discussion}

The summary of the biomass (Mg/ha) potential of the different species in the region is presented in Table 1 . As shown, Mangium (Acacia mangium) has the highest biomass content of $14.383 \mathrm{Mg} / \mathrm{ha}$ one year after establishment. According to Palma (2014), the carbon density in Mangium increases at an early age, however, the increases show a declining rate as the tree approaches maturity which conforms to the findings of Hediyanti and Sulistyawati (2010), Heriansyah et al. (2007) and Peichl and Arain (2006).

Mangium species is also identified as a promising fast growing species. Its biomass projects a significant increase at 4 years from planting with the start of the plant's maturity (Figure 1). However, despite the fast increase in biomass annually, only few tree farmers planted this species due to lack of market and the expense of transporting the logs from the stump site to the mill site (ERDS, 2012). It was observed that Mangium species are heavier due to its denser wood compared to other species used in industrial tree plantations and thus only few logs can be loaded per travel. Nonetheless, because of its wide canopy coupled with relatively fast growth characteristics, this species is a popular choice for rehabilitation of degraded areas. Several provenance trials were established by DENR-ERDS for purposes of improving the variety.

Ipil-ipil (Leucaena leucocephala) at the early development stages generate higher biomass, with $8.210 \mathrm{Mg} / \mathrm{ha}$ during the $1^{\text {st }}$ year and a considerable increase in the $2^{\text {nd }}$ and $3^{\text {rd }}$ year. Singh and Toky (1995) reported that in

\begin{tabular}{|c|c|c|c|c|c|}
\hline \multirow{2}{*}{ Tree species } & \multicolumn{5}{|c|}{ Biomass $\left(\mathrm{Mg} \cdot \mathrm{ha}^{-1}\right)$} \\
\hline & 1 year & 2 years & 3 years & 4 years & 5 years \\
\hline Acacia mangium & 14.38 & 29.23 & 48.66 & 70.61 & 110.64 \\
\hline Paraserianthes falcataria & 0.09 & 18.16 & 25.36 & 31.93 & 125.25 \\
\hline Leucaena leucocephala & 8.21 & 38.13 & 56.61 & 70.41 & 77.36 \\
\hline Eucalyptus deglupta & 0.14 & 5.76 & 23.96 & 40.00 & 58.20 \\
\hline
\end{tabular}

Table 1. Biomass estimates for major industrial tree plantation species in Caraga Region at different ages.

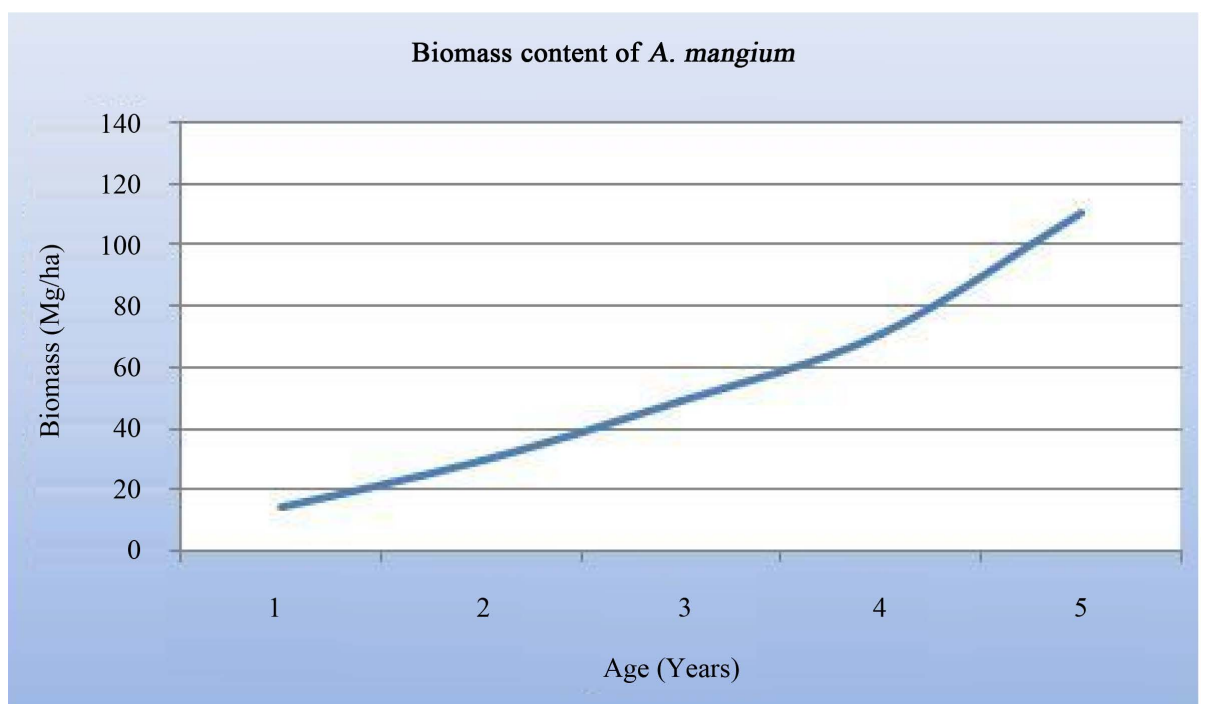

Figure 1. Biomass of Mangium (A. mangium) at different ages. 
4-year-old plantations, with initial plant spacing of $0.6 \times 0.6 \mathrm{~m}$, Leucaena leucocephala showed fairly high net primary productivity ( $33 \mathrm{t}^{-h a^{-1}} \cdot \mathrm{year}^{-1}$ ) given the conditions of arid India. After 8 years of growth, biomass was $126 \mathrm{t}^{\mathrm{h}} \mathrm{h}^{-1}$ in L. leucocephala. In the study of Prasad et al. (2011), they found that tree density significantly influenced biomass production. For L. leucocephala, spacing significantly influenced tree height, diameter at breast height (DBH), number of branches and biomass partitioning at 51 months after planting. Wider planting distance resulted in taller trees with bigger bole, which effected higher per plant productivity.

Ipil-ipil has also high biomass content, with the build-up occurring early in the first 3 - 4 years (Figure 2). Among the trees, it is the fastest growing species during the early years of development given the ecological conditions of Caraga Region, Philippines. Thus it is popularly planted in many areas of the Philippines for fuel-wood use, while some ipil-ipil plantations are also established for forage purposes. Ipil-ipil, due to its Nitrogen-fixing capability being a legume, has been the species used for tree planting since the start of the Tree Planting Program in 1982. This species appears well adjusted to the highly variable ecological conditions of the countryside. Several patches of naturally growing Ipil-ipil can be seen along riverbank serving as an effective means of erosion control.

Bagras (Eucalyptus deglupta) and Falcata (Paraserianthes falcataria) are among the slowest generators of biomass in the $1^{\text {st }}$ year, with $0.141 \mathrm{Mg} /$ ha and $0.089 \mathrm{Mg} /$ ha, respectively as shown in Table 1 . At the early stage of establishment, Falcata has the lowest biomass; however, this species has the highest biomass compared to the other species 5 years after planting. The aboveground biomass of Falcata has a very significant increase in the $5^{\text {th }}$ year while Bagras appeared to have relatively constant growth every year (Figure 3 and Figure 4). Falcata is considered the most favored plantation species among tree farmers in the Caraga Region. Its biomass accumulation is slower during the early developmental stages. However, the increase starting in the 4th year from planting is generally significant. Based on records of the Department of Environment and Natural Resources (DENR), the ERDS (2012) reported that $100 \%$ of the registered plantations have used this species in tree farming, either singly or mixed with other short term crops.

In terms of volume yield of the species, among the major industrial tree plantation species in the region, Ipil-ipil has the highest volume content during the early stage of establishment (Table 2). However, 5 years later, Falcata still have the highest volume yield compared with the other species. This is due to the pattern of growth in Falcata where wood accumulation generally occurs in the $4^{\text {th }}$ year from planting. Bagras, on the other hand, still have the lowest volume with an estimate of only $54.864 \mathrm{cu} \cdot \mathrm{m} / \mathrm{ha}$. Figure 4 shows that growth of Bagras is only moderate thus Bagras production needs to be reconsidered in Caraga Region.

With the spectacular growth rate and suitability for pulp of Bagras, initial enthusiasm among tree farmers was very high. Nonetheless, this has been tempered in many countries in plantations being poorly sited. The species has characteristics that make it unpopular among tree farmers in Caraga Region. It is extremely site-sensitive, very susceptible to fire, does no coppice readily, and is susceptible to a variety of pests and diseases (Eldridge et al., 1993). Paper Industries Corporation of the Philippines (PICOP) has extensive Bagras plantations in Mindanao,

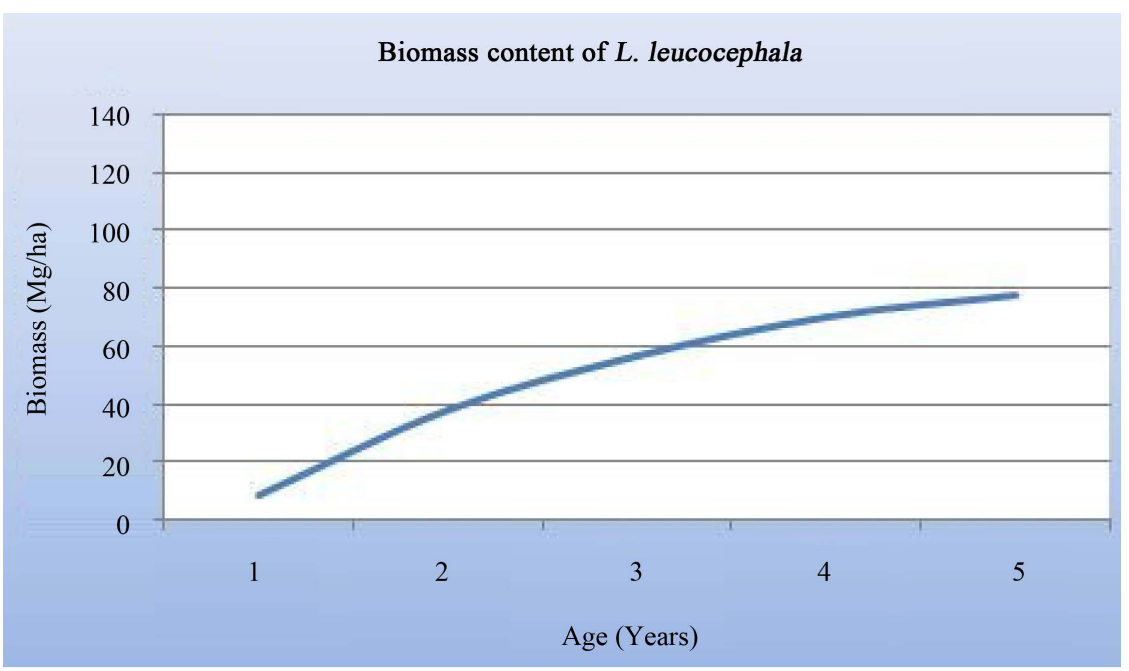

Figure 2. Biomass of Ipil-ipil (L. leucocephala) at different ages. 


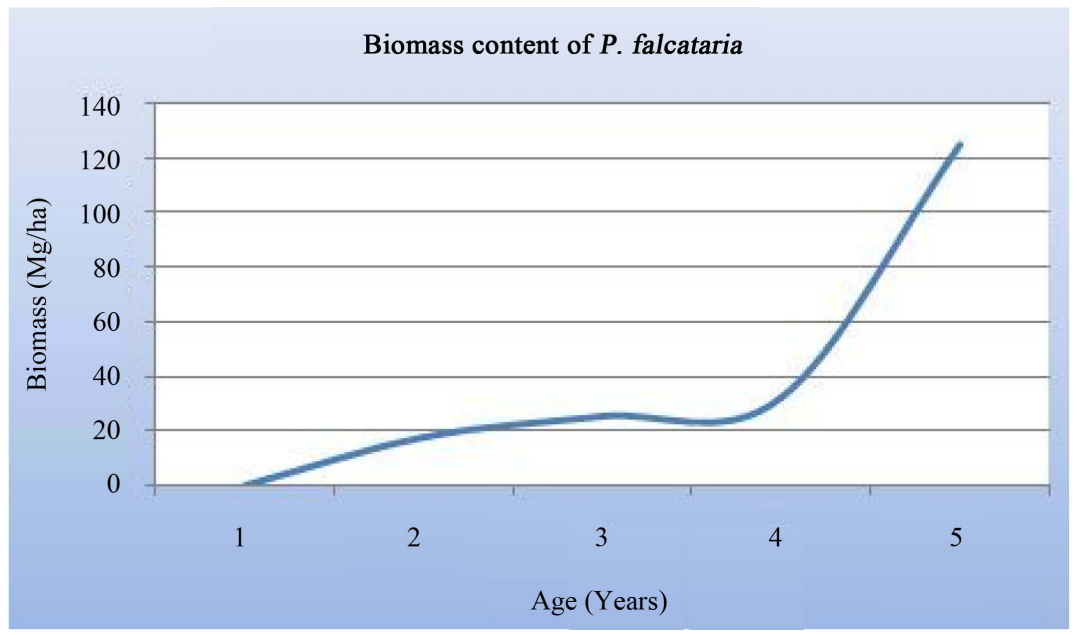

Figure 3. Biomass of Falcata (P. falcataria) at different ages.

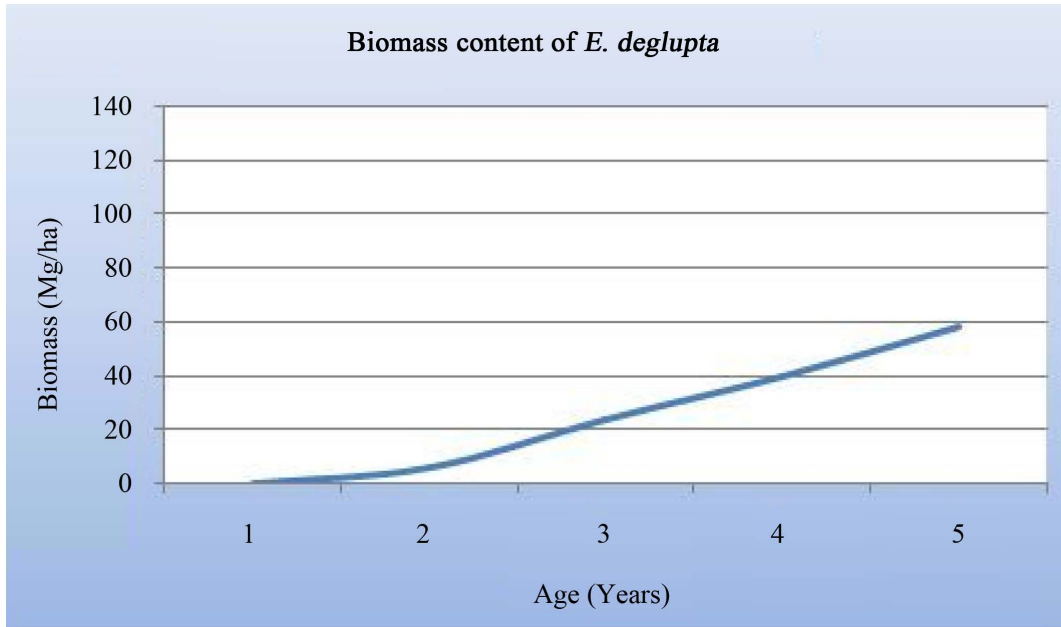

Figure 4. Biomass of Bagras (E. deglupta) at different ages.

Table 2. Summary of volume estimates for major industrial tree plantation species in Caraga Region at different ages.

\begin{tabular}{cccccc}
\hline Tree species & \multicolumn{5}{c}{ Volume $(\mathrm{cu} \cdot \mathrm{m} / \mathrm{ha})$} \\
\cline { 2 - 6 } & 1 year & 2 years & 3 years & 4 years & 5 years \\
\hline Acacia mangium & 5.55 & 22.81 & 48.44 & 78.97 & 145.73 \\
Paraserianthes falcataria & 0.08 & 27.23 & 38.68 & 54.54 & 232.43 \\
Leucaena leucocephala & 6.36 & 32.86 & 50.72 & 64.43 & 131.86 \\
Eucalyptus deglupta & 0.09 & 1.50 & 2.00 & 17.00 & 54.86 \\
\hline
\end{tabular}

however, this species is no longer planted commercially due to significantly slowed growth after 5 years (Eldridge et al., 1993).

\section{Conclusion}

Caraga Region has a wide potential for plantation development to support green energy production considering its favorable environment for industrial tree plantation species. Based on the research findings, the existing industrial tree plantations can be classified as high yielding due to the biomass potential of the 4 major tree species assessed. The high biomass accumulation of the industrial tree species particularly Acacia mangium and 
Paraserianthes falcataria in Caraga Region is promising to supply the raw material requirement of the proposed biomass-based power plant in Caraga Region.

\section{References}

Brown, S. (1997). Estimating Biomass and Biomass Change of Tropical Forests. A Primer. FAO Forest Resources Assessment Publication No. 134. Roma, 55.

Elauria, J. C., Castro, M. L. Y., Elauria, M. M., Bhattacharya, S. C., \& Salam, P. A. (2005). Assessment of Sustainable Energy Potential of Non-Plantation Biomass Resources in the Philippines. Biomass and Bioenergy, 29, 191-198. http://dx.doi.org/10.1016/j.biombioe.2005.03.007

Eldridge, K. G., Davidson, J., Harwood, C. E., \& Wyk, G. V. (1993). Eucalypt Domestication and Breeding. Oxford, UK: Clarendon Press.

ERDS (2012). Semi-Annual Narrative Accomplishment Report for CY 2012. Ecosystems Research and Development Services. DENR Region XIII. Butuan City.

FMB (2013). Philippine Forestry Statistics 2013. Forest Management Bureau, Department of Environment and Natural Resources. www.forestry.denr.gov.ph/PFS2013.pdf

Heriansyah, I., Miyakuni, K., Kato, T., Kiyono, Y., \& Kanazawa, Y. (2007). Growth Characteristics and Biomass Accumulations of Acacia mangium under Different Management Practices in Indonesia. Journal of Tropical Forest Science, 19, 226.

Peichl, M., \& Arain, M. A. (2006). Above- and Belowground Ecosystem Biomass and Carbon Pools in an Age-Sequence of Temperate Pine Plantation Forests. Agricultural and Forest Meteorology, 140, 51-63. http://dx.doi.org/10.1016/j.agrformet.2006.08.004

Prasad, J. V. N. S., Korwar, G. R., Rao, K. V., Mandal, U. K., Rao, G. R., Srinivas, I., \& Kulkarni, H. D. (2011). Optimum Stand Density of Leucaena leucocephala for Wood Production in Andhra Pradesh, Southern India. Biomass and Bioenergy, 35, 227-235. http://dx.doi.org/10.1016/j.biombioe.2010.08.012

Samson, R., Stohl, D., Elepano, A., \& Maio, A. D. (2001). Enhancing Household Biomass Energy Use in the Philippines, Strategies for Enhancing Biomass Utilization in the Philippines. Quebec: Resource Efficient Agricultural Production (REAP). http://dx.doi.org/10.2172/788774

Singh, V., \& Toky, O. P. (1995). Biomass and Net Primary Productivity in Leucaena, Acacia and Eucalyptus, Short Rotation, High Density ("Energy”) Plantations in Arid India. Journal of Arid Environments, 31, 301-309. http://dx.doi.org/10.1016/S0140-1963(05)80034-5

Tandug, L. V. (1986). Biomass Prediction Equation for Giant Ipil-Ipil (Leucaena leucocephala Lam. De Wit.). MS Thesis, Laguna: College of Forestry, UP Los Baños, College. 